\title{
ROLUL PREOTULUI ŞI AL CÂNTĂREȚULUI ÎN CÂNTAREA LITURGICĂ ORTODOXĂ
}

\author{
Costel-Mirel I. V. Nechita*
}

\begin{abstract}
In both the Old and New Testament liturgical music meant connection with God. Christians of the first centuries, recruited from Hebrew, bring with them in the early Church, among other elements or forms of worship and religious chanting psalms from the Old Terstament. Savior and the Apostles were fully agrees with Jewish custom that developed and enriched, especially in the first eight centuries, when there was a full and active participation of the lay faithful in liturgical cult embellishment. Subsequently there is a decline which was mainly due to scarcity of charity. Then remove the historic sacrifice of Calvary meant removing human interior with full understanding of the sacrifices intensity. There has been a real perception offering liturgical symbolism, its message being perceived as weaker. From this was born the lack of frequency to church, losing touch with her servants, believers, its teachings and hymns. The responsibility for resolving this situation has the priest, pastoral singer and other factors that have to use all their knowledge and their example of Christian experience in understanding and living the authentic beauty of Orthodox believers and joy arising from the sacrifice of Calvary. A great role in the development of liturgical worship church fathers have had Masses composition culminating in the fourth century, called gold, and the development of other liturgical texts Sacraments and religious. Growingly liturgical cult was necessary to establish, in addition to higher clergy composed of bishops and priests and deacons and lower clergy represented by the lector, and singer clearly ecclesiastical ministry factors over time until today.
\end{abstract}

Keywords: liturgical worship, singing religious, clergy, priest, deacon, church singer.

* PhD, University of Bucharest. 


\section{Introducere}

Primii creştini, recrutați dintre evrei, aduc cu ei în Biserica primară, printre alte elemente sau forme de cult, şi cântarea religioasă a psalmilor din Vechiul Terstament. Mântuitorul şi Apostolii au fost întru totul de acord cu obiceiul iudaic. Când mulțimea copiilor striga: Osana, fiul lui David, mai-marii preoților şi cărturarii s-au mâniat şi au vrut să-i oprească. Mântuitorul Iisus Hristos apreciază fapta copiilor, zicând: „Oare n-ați citit că din gura pruncilor şi a celor ce sug ți-ai pregătit laudă?” (Psalmul 8, 3; Matei 21, 15-16). După cină, Mântuitorul şi Apostolii, merg în Ghetsimani, cântând psalmi (Matei 26, 30; Marcu 14, 26). Referitor la aceasta, Sfântul Niceta de Remesiana, spune: „Cine se va îndoi chiar de o astfel de dovadă despre sfințenia psalmilor şi a imnelor? Când, Acela Care este închinat şi lăudat de puterile cereşti, El însuşi a adus ca mărturie că a cântat imne cu ucenicii Săi?"' (Fapte 2, 46, 47; IV, 24, $31)$.

Epoca apostolică, fiind epoca harismelor, toți care aveau aceste harisme erau îndemnaţi să le folosească doar spre îmbogăţirea sufletească a celorlalți: „Ce este deci fraților? Când vă adunați împreună, fiecare din voi are psalm, are învățătură, are descoperire, are limbă, are tălmăcire: toate spre zidire să se facă" (I Corinteni 14, 26). După înălțarea Mântuitorului la cer, urmând porunca Lui de a săvârşi permanent jertfa euharistică prin cuvintele „Aceasta s-o faceți întru pomenirea Mea" (I Corinteni 11, 25), Apostolii se adunau şi săvârşeau această jertfă în fiecare zi, contribuind permanent la cristalizarea cultului divin public. Sfântul Apostol Pavel îndeamnă pe creştini: „Prin El aşadar să aducem lui Dumnezeu totdeauna jertfă de laudă, adică roada buzelor care mărturisesc numele Lui" (Evrei XIII, 15). Din Psalmul 49, 14, 23 a trecut în cultul ortodox „Mila păcii, jertfa laudei!'. În veacul apostolic, cântarea cultului divin public era comună. Acelaşi Apostol îi învață pe creştini, spunându-le: „Iar Dumnezeul răbdării şi al mângâierii să vă dea vouă să gândiți la fel

${ }^{1}$ Sf. Niceta de Remisiana, De psalmodiae bono, p. 9. 
unii pentru alții în Hristos Iisus, pentru ca toți într-un gând să măriţi cu o gură pe Dumnezeu şi Tatăl Domnului nostru Iisus Hristos" (Romani XV, 5, 6). La cântarea euharistică, adunarea răspundea: „Amin” (I Corinteni 14, 16).

Conform scrierilor Noului Testament cântările primilor creştini sunt împărţite în grupe astfel:

a) psalmii biblici cu a căror cântare primii creştini erau obişnuiţi de la serviciul templului şi sinagogii;

b) imne sau cântări de laudă, de inspirație mai nouă;

c) cântări bisericeşti, care, după unii autori, sunt cântările de laudă aflate în Scriptură, în afară de psalmi, ca de exemplu: „Slavă întru cei de sus lui Dumnezeu şi pe pământ pace între oameni bunăvoire” (Luca 2, 14), sau: „Măreşte suflete al meu pe Domnul” (Luca 1, 46 ), ori: „Acum slobozeşte” (Luca 2, 29) şi

d) imnele şi cântările bisericeşti, cântarea cea nouă, de care este vorba la Apocalipsă 5, 9. Sunt creaţii spontane şi entuziaste ale primilor creştini. Cele mai multe s-au păstrat mai ales în Apocalipsă (IV, $11 ; \mathrm{XV}, 3,4 ; 19,1,7)$. Se cântau nu numai în locaşurile de cult. De pildă, în închisoare Filipi, Pavel şi Sila lăudau pe Dumnezeu (Faptele Apostolilor 16, 25). Cântările aveau rolul de a umple de cumințenie şi înțelepciune pe creştini, virtuţi ce pot fi dobândite în numele Domnului Iisus, ,ca prin El să mulțumiți lui DumnezeuTatăl"' (Coloseni 3, 7) ${ }^{2}$.

Cântările din epoca apostolică au fost folosite în cult şi în perioada post apostolică, până astăzi. Astfel, într-o scrisoare a lui Pliniu cel Tînăr către Împăratul Teodosie (†112), una din învinuirile aduse de către păgâni creştinilor din părţile Pontului şi ale Bitiniei era că ,ei se adună într-o sâmbătă (duminică) şi cântă alternativ imne lui Hristos, ca lui Dumnezeu"3.

${ }^{2}$ Costel-Mirel I. V. Nechita, Pastorația prin muzică, Sibiu, Editura Arhip Art, 2009, pp. 94-97.

${ }^{3}$ Scrisoarea lui Pliniu cel Tînar către Împaratul Traian, Epistolarum liber, X apud, Ene Branişte, Temeiuri biblice şi tradiționale pentru executarea cântării in comun a credincioşilor, S. T. VI, 1954 p. 21, p. 97. 
Într-o versiune siriacă a Apologiei lui Aristide, scrisă în jurul anului 140, citim: „Creştinii se adunau în fiecare dimineață şi în fiecare ceas, pentru binefacerile lui Dumnezeu spre ei; ei cântă laudele sale şi îi dau slavă"’ .

Pe la mijlocul secolului al II-lea, Sfântul Iustin Martirul ne spune că pe vremea lui, în adunările liturgice, după citirea Evangheliei şi predica episcopului „ne ridicăm toți în sus şi facem toți rugăciuni. Apoi, după ce proestosul rosteşte rugăciunea pentru sfințirea darurilor de pâine şi de vin, tot poporul de față exclamă zicând: Amin!"5. Ulterior, alături de psalmi şi imnele biblice, încep să apară imne noi cu conținut doctrinar, dintre care, Sfântul Vasile

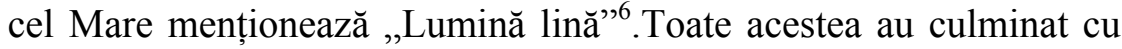
Liturghiile din secolul al IV-lea, secolul de aur al creştinismului. Ulterior, cultul liturgic ortodox a fost îmbogățit cu alte slujbe religioase alcătuite de către Părinții Bisericii.

Căderea sub ocupația turcească şi a altor popoare necreştine care au cotropit teritorii creştine a dus la o pierdere a contactului cu cântarea comună universală a Bisericii de până atunci.

În Biserica Ortodoxă Română, până în secolul al XVI-lea, limba liturgică folosită în cântarea în comun era în exclusivitate cea paleoslavă, de la această dată începând să se folosească treptat şi cea română. În secolul al XVIII-lea, limba noastră a înlocuit definitiv vechea slavă şi greacă, ce se infiltrase în unele biserici. Meritul limbii noastre liturgice constă în faptul că ea reprezintă o sinteză între limba veche bisericească şi cea vorbită de popor, păstrând caracterul arhaic şi frumusețea traducerilor vechi bisericeşti, dar ținându-se seama şi de evoluţia limbii liturgice şi a celei populare. În felul acesta s-a putut realiza pastorația clară şi profundă prin muzică. Referitor la claritatea mesajului liturgic, Mitropolitul Dosoftei, parafrazându-l pe Sfântul Apostol Pavel, spune: „În Biserică mai voia mi-i cinci cuvinte cu mintea să grăiesc ca şi pe alții să-nvăț,

\footnotetext{
${ }^{4}$ Idem, citat din Dict. d' Archeal, Chrit. et de Liturgie, VI, col. 28.

${ }^{5}$ Sf. Iustin Martirul, Apologia, cap. LXV şi LXVII.

${ }^{6}$ Sf. Vasile cel Mare, Despre Sfântul Duh, 29, 73 la Migne P. G. XXXII, col 205.
} 
decât zece mii de cuvinte într-altă limbă”. Limba folosită în cult fiind limba română, a dat posibilitatea credincioşilor să participe efectiv la cântările cultului. De aceea Sfânta Liturghie este ştiută de majoritatea credincioşilor.

La noi cântarea comună, ca mijloc de pastorație colectivă, a fost privită la început cu rezervă. Ea s-a impus mai întâi în Ardeal, atât la ortodocşi cât şi la uniţi. Era însă folosită de multă vreme în biserica de dincoace de munți, mai ales la Prohodul Domnului.

Cântarea corală bisericească este introdusă în secolul al XVIIIlea, reprezentând tot o formă de cântare obştească, membrii corului, oameni laici sau din clerul inferior, fiind reprezentanții în cântare a celorlalți credincioşi. Din anul 1950, Sfîntul Sinod reaminteşte credincioşilor mireni dreptul de a participa activ la cântarea, citirile şi rugăciunile cultului. S-a hotărât ca toate cărțile de cântări bisericeşti să se tipărească monodic, fără să se excludă posibilitatea cântării polifonice. Ulterior s-au uniformizat cântările bisericeşti ce nu erau peste tot la fel în Biserica noastră. S-a luat ca bază muzica tradițională adusă din Bizanț, trecută prin specificul artistic de la noi şi adaptată la însuşirile etnice ale românilor, după diferiţi autori români, alcătuitori de melodii liturgice.

\section{Cuprins}

Nimeni şi nimic nu a putut înăbuşi sau stăvili dragostea creştinilor dintru început de a săvârşi, după îndemnul Mântuitorului, jertfa cea nesângeroasă, spre aducere-aminte şi spre împărtăşire cu El Însuşi şi de a înălţa împreună imne lui Dumnezeu; nici prigonitorii, nici lipsa spațiilor în care să-şi desfăşoare cultul, nici supărările ce veneau din partea celor ce nu înțelegeau frumusețea şi profunzimea noii religii.

Cântarea psalmilor în primele secole se făcea, aşadar, responsorial, după modelul evreilor din Vechiul Testament. Când unul cântă în biserică, se roagă toți prin el. Cântarea responsorială presupune tăcerea grupului, în timp ce unul cântă. Cuvintele le rosteşte acela, dar le cântă şi mintea şi sufletul celorlalți. Cântarea 
liturgică comună a avut un rol bine definit în toate timpurile, referindu-ne desigur, pe lângă efectul pastoral provocat în sufletul ascultătorilor, la cel didactic, aprofundat, prin îmbrăcarea textului în muzică şi la efectul estetic, de înfrumusețare a cultului divin public. Îmbogățirea cultului ortodox s-a făcut în timp. Permanent au apărut elemente noi, concretizate în gesturi liturgice cu explicație practică sau simbolică, cântări noi şi multe alte elemente necunoscute pentru cei ce pierd legătura cu Biserica. De aceea, pentru buna desfăşurare a slujbelor liturgice, a fost necesară apariția unei noi instituții în Biserică, numită a clerului inferior, reprezentată liturgic şi prin cântărețul bisericesc, ${ }^{7}$ un reprezentant al credincioşilor cu talent şi pregătire muzicală mai deosebite.

În cântarea responsorială, cântărețul începea psalmul, cânta un verset, iar credincioşii continuau cântarea sau răspundeau după fiecare verset cu un refren, care era, fie un verset din psalm, de exemplu: „Că în veac este mila Lui” (Psalmul 135), fie o exclamație rituală, Aliluia, fie o formulă tezistă ocazională.

Din secolul al IV-lea înainte, odată cu apariția imnelor noi doctrinare, se inaugurează un nou mod de cântare: cea antifonică sau alternativă, adică două cete ce cântau la unison şi alternativ. Pe la mijlocul secolului al IV-lea, ambele moduri erau încă în vigoare, întrebuințate la aceeaşi biserică şi la aceeaşi slujbă, când unul când altul. Sfîntul Vasile cel Mare răspunde unor obiecții asupra felului cum era organizată biserica în eparhia lui. Spune că ,această organizare este aceeaşi din toate bisericile din vremea aceea". Credincioşii se scoală din noapte şi merg la locul de rugăciune. După ce s-au rugat, trec la psalmodie. Uneori ei se împart în două cete care cântă alternativ; alteori lasă pe un solist (cântăreț) să cânte şi toți ceilalţi îi răspund. Iar după ce au petrecut astfel noaptea cu diferite psalmodii, ei intonează laolaltă, ca dintr-o gură şi o inimă psalmul mărturisirii - Psalmul 91: „Bine este a ne mărturisi Domnului”; după

${ }^{7}$ Costel-Mirel I. V. Nechita, op. cit. , p. 116. 
alții, Psalmul 57 sau $63 .{ }^{8}$ Celor care îl acuzau pe Sfîntul Vasile cel Mare că face rugăciuni şi privegheri prea lungi, amenințând cu despărţirea de biserică, el le răspunde: „Dacă acesta este motivul pentru care vreți să vă despărțiţi de mine, apoi trebuie să o rupeți şi cu credincioşii din Egipt, cu cei din cele două Libii, cu cei din Tebaida şi din Palestina, cu Fenicienii, Sirienii şi Arabii, cu cei ce locuiesc pe malurile Eufratului, într-un cuvânt cu toți cei cărora le plac vegherile sfinte, rugăciunea şi cântarea în comun". ${ }^{9} \mathrm{Cu}$ timpul, cântarea responsorică dispare şi rămâne cea antifonică.

Eusebiu, episcopul Cezareii (†340?), ne informează că începând din secolul al IV-lea ,îndemnul de a cânta psalmi în numele Domnului e observat pretutindeni". În a doua jumătate a secolului IV, o călugăriță apuseană, Silvia sau Aetheria, face un pelerinaj la locurile Sfinte în preajma Paştelui. Ea descrie participarea masivă a credincioşilor la cântarea religioasă. În duminica stâlpărilor, când aveau loc procesiuni, tot poporul mergea înaintea episcopului, cântând imne şi antifoane, repetând des refrenul: „Bine cuvântat cel ce vine întru numele Domnului". ${ }^{10}$ Tot ea spune că la ectenia de la vecernie, glasurile lor nenumărate (quorum vocei infinitae sunt), răspund Kyrie eleison. În Biserica Învierii, unul dintre preoți zice un psalm şi răspund toți. În zelul lor pentru cântarea imnelor excelau acei monazontezi şi partheni - monahi şi fecioare (călugăriţe) ce trăiau în mijlocul lumii cu rugăciuni şi vegheri, cântând imne sau antifoane.

Sfântul Ioan Gură de Aur dă norme pentru disciplina cântării în Biserică, silindu-se să impună şi să păstreze caracterul religios al cântării liturgice, combătând tendințele unora de a introduce în

${ }^{8}$ Sf. Vasile cel Mare, Epistola CCVII, 3, Către clericii din Neo-Cezareaa, Migne, P. G. XXXII, col. 761-764.

${ }^{9}$ Ibidem.

${ }^{10}$ Sanctae Silvae peregrinatio, Viena 1898, apud, Ene Branişte, st. cit , pp. 83, 84. 
bisericile creştine modul lumesc, al cântărilor din teatre şi de la jocuri sau de la diferitele reprezentații creştine. ${ }^{11}$

În secolul al V-lea Fericitul Ieronim $(\uparrow 420)$, pornind de la „...în inimile noastre...” (Efeseni V, 19), se adresează tineretului care cântă în Biserici, şi-i învață că lui Dumnezeu trebuie să-i cântăm atât cu glasul, cât i cu inima. ${ }^{12}$ Închinătorii trebuie să cânte în aşa fel ca să facă plăcute cuvintele ce le cântă, şi nu pentru a-şi pune în evidență frumusețea glasului.

Pe timpul epioscopului Gherman al Parisului, secolul al VI-lea, poetul latin Venantius Fortunatus scrie că la Paris, la îndemnul Episcopului, cântă şi clerul şi poporul şi copiii (Pontificis monitis, clerul, plebs psallet et infans).

Participarea masivă, deplină şi activă a credincioşilor laici la cultul liturgic s-a realizat în chipul cel mai strălucit în primele şapteopt secole după care, ceva mai redusă şi în următoarele secole. Apoi, condiții obiective şi subiective duc la diminuarea frecvenței la slujbele religioase.

Liturghia bizantină, devenită de mult liturghia întregii creştinătăţi ortodoxe, este nu atât simbolul şi expresia cea mai palpabilă a unității în duh a Ortodoxiei de pretutindeni, cât slujba cea mai importantă a Bisericii, unde în chip nesângeros se reactualizează jertfa de pe Golgota şi unde, credincioşi şi cler, adunaţi în rugăciune şi cântare comună, imploră harul Duhului Sfânt ce transformă pâinea şi vinul în Însuşi Trupul şi Sângele Mântuitorului. În cadrul acestei slujbe, forma cea mai frecventă de rugăciune şi cântare comună este Ectenia - dialogul liturgic, la care poporul răspunde cu rugăciunea Doamne miluieşte. După ectenii, preotul citeşte rugăciuni în taină, în timp ce credincioşii cântă psalmi sau imne liturgice. Apostolul poate

\footnotetext{
${ }^{11}$ Sf. Ioan Gură de Aur, Cuvânt de laudă la cei adunați în biserică şi despre buna rânduială în cântare, 2 Migne; P. G. L, VI col 99.

${ }^{12}$ Fericitul Ieromin, Comentar la Epistola către Efeseni, cartea III, cap. V, Migne; P. L. XXV col. 561, 562.

${ }^{13}$ Poema in laud cleri, Paris, Migne, P. L. LXXXVIII, col. 104, apud, Ene Branişte, st. cit.
} 
fi citit tot de un credincios. La rugăciunea Sfintei Jertfe, preotul şi poporul se unesc din nou în dialog de rugăciune şi cântare. Pace tuturor rosteşte preotul iar credincioşii răspund: Şi duhului tău. Sus să avem inimile, îndeamnă preotul. Avem către Domnul, asigură credincioşii pe preot. Toată Sf. Liturghie este un dialog permanent între preot şi credincioşi care formează în felul acesta o unitate rugătoare. Toți într-un glas şi într-un elan plin de umilință şi cucernicie invocă trimiterea Duhului Sfânt. Tot ei rostesc împreună Crezul şi Tatăl nostru. În Ortodoxie, Sfânta Liturghie îşi păstrează valoarea ei autentică, fiind cea mai veche Liturghie a Bisericii primare, îmbogăţită şi dezvoltată ulterior fără să aibă nevoie de refacere sau înnoire, cum se simte azi în Biserica Romano-Catolică sau în Biserica Anglicană.

Îmbogățindu-se cultul liturgic în afară de cântările Sf. Liturghii înstituția clerului inferior din care făcea parte şi cântărețul liturgic capătă o importanță mai profundă fiind privită mai atent de Părinţii Bisericii şi de hotărârile Sinoadelor ecumenice. Apar reguli de interpretare a cântărilor de către cântăreți numiți de acum canonici, care sunt îndemnați să nu silescă firea spre răcnire.

Un comentariu liturgic, atribuit Sfântului Sofronie al Ierusalimului (†638), ne informează: „Credincioşii cântă alături de cântăreții canonici”. După ieşirea cu Sfânta Evanghelie, cântăreții se suie pe amvon şi cântă: „Veniți să ne bucurăm de Domnul... La aceasta îşi unesc glasurile şi cei de jos"14. Mai târziu cântăreții îndeamnă pe credincioşi la Cântarea heruvicului, pe care ei o zic în acelaşi timp cu toți. ${ }^{15}$ Sfântul Simeon al Tesalonicului aminteşte şi el de cântăreți, mai ales la alte servicii decât la Sfânta Liturghie, la care e necesar să se execute cântări mai întinse şi cu un grad de dificultate sporit, pe care nu le pot executa toți.

\footnotetext{
14 Sf. Simeon al Tesalonicului, Explicare despre Sf. biserică, trad. rom. Bucureşti, 1866, p. 266 şi Despre Sfânta Liturghie, cap. XCVIII trad. rom. , Bucureşti, 1866, p. 106.

${ }^{15}$ Sofronie al Ierusalimului, Cuvînt cuprinzînd întreaga descriere a Bisericii, Migne, P. G. LXXXVII col. 3993 d.
} 
Explicarea liturgică a lui Meletie Sirigul inserată în scrisoarea sinodală a Patriarhului ecumenic Paisie I către Patriarhul Nifon al Moscovei (1655), ne arată cum cântarea antifonică din liturghie era executată de psalți, dar Sfinte Dumnezeule îl cânta credincioşii ca şi rostirea Crezului. ${ }^{16}$ La toți tâlcuitorii Sfintei Liturghii, Crezul şi Tatăl nostru apar ca fiind rostite de tot poporul, lucru ce se obişnuieşte şi astăzi în majoritatea bisericilor creştine. De asemenea, Canonul 15 al Sinodului de la Laodiceea, referitor tot la rolul cântărețului, prevede: „Afară de cântăreții canonicești, cari se urcă pe amvon şi cântă din carte, altora nu li se permite să cânte în Biserică”. $17 \mathrm{Nu}$ trebuie înțeles însă că acest canon interzice dreptul credincioşilor de a cânta în Biserică. Psalții sau cântăreții canonici de care vorbeşte canonul erau cântăreții anume orânduiți de biserică prin hirotesie specială, fiind înscrişi în canon ca făcând parte din catalogul clericilor inferiori. Canonul este una din cele mai vechi mărturii despre existența psalților în Biserica creştină, ca dedublare a instituției mai vechi de anagnost (lector sau citeț), născută din nevoia supravegherii şi cultivării sau îmbogăţirii psalmodiei liturgice, ce începuse să se denatureze datorită cauzei amintite, cât şi neglijenței cu care erau executate cântările de cântăreții neinstruiți.

Până în secolele IV-V nu existau decât psalmii biblici, care erau ştiuți de către toți. Cântarea bisericească era deci o psalmodie cântată în stil responsoric, procedeu descris în Constituțiile Apostolice: „Cineva să cânte psalmii lui David iar credincioşii să răspundă acrostihurile (refrenurile)". ${ }^{18}$ Solistul sau psaltul se evidenţiază doar prin volum şi calitatea vocii ce era mai puternică, mai frumoasă şi mai cultivată. El avea rolul să-i învețe pe credincioşi cum să cânte în Biserică. Într-o inscripție păstrată pe mormântul unui psalt din cetatea Adriani în Asia Mică (sec. III), concetățenii lui îi aduc omagii postum pentru că a fermecat cu vocea şi cu cântarea turma lui Dumnezeu Cel Prea Înalt şi că a instruit pe toți credincioşii

\footnotetext{
${ }^{16}$ Ibidem, col. 4000 D, col. 4001 a.

${ }^{17}$ Nicolae Milaş, Canoanele B. O. , trad. rom. Vol II, partea I, p. 94.

${ }^{18}$ Constituțiile apostolice, cartea II, cap. LVII.
} 
în cântarea psalmilor sfinţi şi în citirea cărţilor sfinte. ${ }^{19}$ Constatăm aşadar că rolul cântărețului nu a fost şi nu este de a cânta numai el singur, ci şi de a conduce executarea cântărilor. În vechime, el dădea semnalul şi tonul rostind sau cântând versete, iar ca să fie văzuți şi auziți, se urcau în amvon, executând cântarea de pe manuscrisul de piele şi de pergament, în formă de carte (codice) sau rulou (sul) cu cântări canonice sau oficiale. E posibil ca pe acestea să fi fost scrise psaltirea şi alte cântări din Biblie. În unele documente, psaltul este numit praecentor, pronunțiator de psalmi, psalmorum modelatorum, iar Sozomen îi numeşte pe cântăreți monitores, inspiratores, adică supraveghetori sau dirijori ai celor ce cântă în Biserică. ${ }^{20}$

Canonul de la Laodiceea viza aşadar pe acei solişti improvizați care, fără consacrarea Bisericii şi fără pregătirea necesară, începeau imnele, luând-o înaintea cântăreților oficiali. A fost o măsură disciplinară a sinodalilor.

În primele veacuri, trecerea la creştinism fiind masivă, atrăgea după sine incompetență în cântarea liturgică, ce venea din necunoaşterea acesteia şi încercarea de introducere în biserică a melodiilor profane sau păgâne precum şi pătrunderea psalmilor privați sau particulari, imne noi necanonice şi nescripturistice, cum era cazul psalmilor donatişti în Africa. Părinții urmăreau totodată conservarea şi păstrarea liniei clasice a cântărilor şi prohibirea cântărilor canonice. Canonul 59 interzicea acelaşi lucru: să nu se citească şi să nu se cânte din alte cărți decât din cele canonice.

Cântăreții de astăzi au apărut datorită necesității crescânde a cultului. Ei cântă dimpreună cu preotul şi cu poporul credincios şi nu în locul lor. Înfrumusețarea cultului prin poezia imnografică, (tropare, condace, canoane) şi sistematizarea cântărilor prin gruparea lor în cele 8 glasuri de către Sfântul Ioan Damaschin în sec. al VIII-

${ }^{19}$ Ene Branişte, st. cit. , text tradus din franceză a inscripției în Dict. d' Archiol, Chret. et de Liturgie, III, col. 344, 345.

${ }^{20}$ Sozomen, Istoria Bisericească, cartea V, cap. XXII, Migne P. G. LXVII, coI. 636. 
lea a dus, totuşi, la o departajare între cler şi credincioşi. Greutatea executării cântărilor ce ține de un dat nativ fructificat a atras după sine imposibilitatea executării lor de către toți credincioşii, acestea rămânând în seama cântărețului, unirea glasurilor în cântare comună realizându-se deplin în Sfânta Liturghie şi parţial în anumite cântări ce însoțesc alte slujbe liturgice.

Ruptura masivă de la care credincioşii au foarte mult de suferit în ce priveşte legătura lor cu cântarea comună a bisericii este cauzată de căderea sub ocupație turcească, ocupație ce a căutat să nimicească valorile neprețuite ale creştinismului. La noi nu a mai fost posibilă participarea credincioşilor la cult după introducerea limbii slave vechi în Biserică. În majoritatea Bisericilor Ortodoxe, cântarea credincioşilor a fost lăsată pe seama cântăreților şi ulterior a corului, mai ales la Sf. Liturghie şi unele Sf. Taine şi Ierurgii. În Răsărit, la eterodocşi, s-a păstrat cântarea comună la armeni, sirieni, monofiziți, unde toată lumea cântă în Biserică, cele mai multe cântări fiind cunoscute pe dinafară. În Biserica Ortodoxă, cântarea comună s-a păstrat mai ales în Biserica Rusă, iar la noi a reînviat după introducerea limbii române în cult.

\section{Concluzii}

Necesitatea aplicării în practică a canonului 15 de la Laodiceea se simte astăzi mai mult ca oricând datorită , , invaziei', cântăreților neinstruiți în Bisericile ortodoxe şi cu precădere la noi în țară. Comparativ cu primele veacuri creştine, frecvența credincioşilor la biserică este mult mai redusă, aceasta în mare parte şi din cauza neprofesionalismului de care dau dovadă aşa-zişii cântăreți de astăzi. Revenirea unui creştin, depărtat mult timp de Biserică, înseamnă în primul rând reântâlnirea $\mathrm{cu}$ muzica ei, reprezentată prin preot şi cântăreț dimpreună cu poporul credincios care aduce slavă prin cântarea liturgică. Lipsa de profesionalism, cauzată de cele mai multe ori din plafonare şi delăsare, atrage după sine repulsia credincioşilor ce nu mai înțeleg mare lucru din ceea ce se cântă. 
Slujba liturgică este concepută şi construită ca să aibă cursivitate şi frumusețe. Mesajul textului liturgic este însă clar doar atunci când cântărețul se preocupă în particular de studierea sensului sau sensurilor acestuia, pentru ca, îmbrăcându-l în haina frumoasă a muzicii, să-l canalizeze spre mintea credincioşilor dornici de înțelegere. De aici necesitatea şcolilor de cântăreți, ce trebuie să observe nu numai calitatea vocii şi exprimarea clară, ci şi urmărirea îndeaproape a elevilor componenți în ce priveşte aprofundarea şi înțelegerea învățăturilor sfinte. Una din cauzele apariției sectelor este şi nesatisfacerea sufletească a credincioşilor, ce vine întâi prin auz.

Personal, cred că mare parte din frumusețea slujbei liturgice este relizată şi de cântăreț. Preotul are rolul său bine definit, superior, fiind intermediar între cer şi pământ, coborând prin rugăciune şi cântare harul lui Dumnezeu în viața credincioşilor. Un cântăreț cu un înalt profesionalism şi cu o trăire creştinească exemplară este un alt pilon ce ajută pe preot în misiunea amintită. $\mathrm{Cu}$ nimic nu trebuie minimalizat rolul celor doi. Numai cine a trăit şi experimentat frumusețea cântărilor liturgice îşi dă seama ce înseamnă un cântăreț bisericesc bine pregătit şi format moral şi muzical. El este reprezentantul rugăciunii cântate a poporului. Prin efortul său, cântă întreaga Biserică, ajutându-1 pe preot să se concentreze mai degrabă la cele ce are de făcut. Întotdeauna instituţia cântăreților a fost privită cu seriozitate, cei dornici de a intra în ea trecând prin anumite trepte cum ar fi cea de citeț sau lector, canonist şi isonar, treaptă mai puțin înțeleasă astăzi.

Isonul a însoțit cântarea liturgică dintru început. El însoțeşte solistul sau grupul de cântăreți, şi îşi aduce, în felul acesta, aportul acompaniamental în cântarea liturgică. Isonul, executat corect, odihneşte atât pe isonar cât şi pe ascultători. Cel ce ține isonul este mai atent la textul cântării decât, uneori, cel ce cântă melodia, care poate pierde de multe ori firul ideii, din nestudierea clară a textului sau poate scăpa din vedere firul transpunerii în plan duhovnicesc, cauzat de cele mai multe ori din mândrie ori din alte motive: voce frumoasă, priviri aruncate pline de admiraţie de cei din jur ş. a. Am putea spune că isonul este trâmbița îngerilor şi fondul de aur al 
icoanei. Muzica bizantină nu poate fi concepută fără ison, ce indică în general tonica cântării respective. Ținerea isonului este o şcoală şi o artă pe care din păcate mulți o ignoră. Li se pare că îndemnul la a ține isonul este o umilință sau o dorință a altora de a se afirma cu ajutorul lor. La această probă de noviciat erau supuşi în vechime cei dornici de a intra în tagma cântăreților. Şi proba ținea până când aceştia, ascultând prin rugăciunea isonului, învățau cântările de la cei perfecționați în executarea lor, schimbarea isonului în funcție de melodia cântecului fiind garanția receptării mai uşoare a cântărilor liturgice. Apropierea astăzi de strană a multor necunoscători într-ale armoniei, ce provoacă de multe ori o mare tulburare, întâlnită mai ales la hramurile bisericilor, unde fiecare încearcă să-şi „etaleze”, darul primit, vine şi din lipsa cântăreților de altă dată, pe care ascultându-i, nu cred că ai fi avut curajul să te apropii de strana unde aceştia cântau, dacă nu aveai cunoştințele necesare.

Nu-mi propun să-i nominalizez pe marii cântăreți sau compozitori de cântări sfinte, deoarece nu acesta este scopul studiului de față, ci doar să scot în evidență faptul că ar rămâne dezolaţi şi stupefiaţi dacă ar asculta unii cântăreți nepregătiţi profesional din timpurile noastre, precum şi felul în care sunt executate cântările compuse şi cântate cândva de ei.

În țara noastră, mai ales după 1989, se observă un lucru şi mai dăunător pentru biserică: pericolul laicizării (ca şi în veacul apostolic) cântărilor cultice şi executarea acestora într-o măsură slabă, cauza fiind necunoaşterea adevăratei muzici a Bisericii de către cântăreții ce sunt antrenați din ce în ce mai mult în cântare, indiferent de felul în care cântă. Se constată, mai ales în ultimul timp, în țara noastră, o asaltare a bisericilor de către cântăreții de la operă, care silesc firea spre răcnire, tulburând prin glasul lor necontrolat şi prin cântările laicizate bunul mers al rânduielilor bisericești. Să nu fiu înţeles greşit! O apropiere a cântăreților, indiferent de stilul de muzică pe care o practică la nivel profesional: operă, filarmonică, uşoară, populară, rock etc. de muzica bisericii este un dublu câştig pentru ortodoxie: pe unii dintre ei ca persoane şi convertirea şi înălțarea multora prin muzica lor. Dar nu apropiere oricum şi cântare 
după preferință, ci o apropiere sinceră cu dorință de întoarcere şi studiu aprofundat al muzicii bizantine, mai ales că acest lucru este mult mai accesibil lor, care sunt cunoscători ai notației liniare ce poate fi studiată comparativ cu cea psaltică, grație muncii de transcrierii pe ambele notații a majorității cântărilor bisericeşti, mai ales după anul $1989^{21}$.

Cântărețul este aşadar un fel de preot laic ce-şi exercită misiunea prin cântare şi exemplu personal. Este benefică pentru întreaga Ortodoxie înființarea a cât mai multor şcoli de cântăreți, care să pregătească reprezentanţi ai creştinilor dornici de a-şi cultiva şi înălța sufletul prin muzică, lucru realizat într-o oarecare măsură astăzi, dar asupra căruia trebuie insistat mai mult. E adevărat că , , preotul este responsabil de buna organizare a cântării religioase în parohie şi tot el este cel care trebuie să selecteze atent cântările şi pricesnele ce se cântă în biserică" ${ }^{\text {"22 }}$ dar pentru a se realiza acest lucru benefic cultului liturgic trebuie şi cântăreți pregătiţi în şcoli, altfel, prin cântatul , , după auz" se poate ajunge la fenomenul din Bucovina şi Ardeal din timpul ocupației Austro-ungare. Salvarea acestei situații şi a tezaurului cântărilor liturgice bine învățate şi executate ține, aşadar, de înființarea cât mai multor şcoli de cântăreți şi a angajării cântăreților bisericeşti calificați în fiecare parohie creştin-ortodoxă românească.

\section{Bibliografie:}

1. Adam, Domin, Trecut, prezent şi viitor în muzica bisericească românească (contribuții radiografice muzicale), în „Altarul Reîntregirii”, Serie nouă, Anul XVIII, Nr. 3, septembrie-decembrie, 2013.

2. Scrisoarea lui Pliniu cel Tînar către Imparatul Traian, Epistolarum liber. apud, Branişte, Ene, Temeiuri biblice şi tradiționale pentru executarea cântării în comun a credincioşilor, S. T. VI, 1954.

${ }^{21}$ Costel-Mirel I. V. Nechita , op. cit. , p. 121-125.

${ }^{22}$ Domin Adam, Trecut, prezent şi viitor în muzica bisericească românească (contribuții radiografice muzicale), în „Altarul Reîntregirii”, Serie nouă. Anul XVIII, Nr. 3, septembrie-decembrie, 2013, p 19. 
3. Dict. d' Archeal, Chrit. et de Liturgie, VI, apud idem.

4. Poema in laud cleri, Paris, Migne, P. L. LXXXVIII, apud Idem.

5. Sanctae Silvae peregrinatio, Viena, 1898, apud Idem.

6. Constitutiile apostolice, cartea II.

7. Fericitul Ieromin, Comentar la Epistola către Efeseni cartea III, cap. V, Migne; P. L. XXV.

8. Milaş, Nicolae, Canoanele B. O. , trad. rom. Vol II, partea I.

9. Nechita I. V, Costel-Mirel. , Pastorația prin muzică, Editura Arhip Art, Sibiu, 2009.

10. Sf. Ioan Gură de Aur, Cuvânt de laudă la cei adunați în biserică şi despre buna rânduială în cântare, 2 Migne; P. G. LVI.

11. Sf. Iustin Martirul, Apologia, cap. LXV şi LXVII.

12. Sf. Niceta de Remisiana, De psalmodiae bono.

13. Sf. Simeon al Tesalonicului, Explicare despre Sf. biserică, trad. Bucureşti, 1866.

14. Idem, Despre Sfânta Liturghie, cap. XCVIII trad. rom. , Bucureşti 1866.

15. Sf. Vasile cel Mare, Despre Sfintul Duh, 29, 73 la Migne P. G. XXXII.

17. Idem, Epistola CCVII, 3, Către clericii din Neo-Cezareaa, Migne, P. G. XXXII.

18. Sofronie al Ierusalimului, Cuvînt cuprinzînd întreaga descriere a Bisericii, Migne, P. G. LXXXVII.

19. Sozomen, Istoria Bisericească, cartea V, cap. XXII, Migne P. G. LXVII. 